\title{
Analisis Karakteristik Spasial Kawasan Permukiman dengan Spatial Metric di Distrik Jayapura Selatan, Kota Jayapura
}

\author{
Citra Andinasari dan Cahyono Susetyo \\ Departemen Perencanaan Wilayah dan Kota, Fakultas Arsitektur, Desain dan Perencanaan, \\ Institut Teknologi Sepuluh Nopember (ITS) \\ e-mail: cahyono_s@urplan.its.ac.id
}

\begin{abstract}
Abstrak-Kawasan permukiman di Kota Jayapura semakin meningkat setiap tahunnya dan bertumbuh secara massif membentuk kawasan permukiman informal akibat kondisi topografi maupun ekonomi masyarakat setempat. Sehingga kawasan permukiman bertumbuh dengan karakteristik spasial yang berbeda-beda. Tujuan dari penelitian ini adalah untuk mengetahui karakteristik spasial kawasan permukiman di Kota Jayapura dengan menggunakan analisis spatial metric. Dari hasil analisis tersebut dapat disimpulkan bahwa kedua Kawasan yang menjadi objek penelitian memiliki karakteristik spasial yang berbeda. Kawasan Permukiman Jaya Asri memiliki nilai metrik PD, LPI, AREA_MN yang lebih besar dan nilai metrik LSI yang lebih sedikit dibandingkan Polimak. Dengan kata lain Jaya Asri yang merupakan salah satu permukiman terencana di Kota Jayapura memiliki karakteristik spasial yakni pola bangunan yang lebih kompak, memiliki rata-rata bangunan yang lebih luas dan berbentuk lebih regular jika dibandingkan dengan Polimak yang merupakan salah satu permukiman tidak terencana di Kota Jayapura.
\end{abstract}

Kata Kunci-pola bangunan, Kawasan permukiman, spatial metric

\section{PENDAHULUAN}

$\mathrm{K}$ AWASAN permukiman perkotaan di negara berkembang memiliki perkembangan yang tidak direncanakan [1]. Arus urbanisasi yang tidak terkendali menyebabkan tekanan perkembangan perkotaan yang pesat tanpa adanya manajamen dan perencanaan sehingga berujung pada berkembangnya daerah-daerah yang tidak direncanakan [2]. Dimana beberapa kawasan permukiman berkembang secara pesat mendekati pusat kota karena kedekatan akan peluang pekerjaan, beberapa permukiman lainnya berkembang di pinggiran perkotaan. Perkembangan perkotaan tersebut dapat mengakibatkan fenomena seperti kemacetan, transportasi public, infrastruktur dan sanitasi yang kurang layak. Hal tersebut menunjukkan perlunya penelitian terkait pertumbuhan permukiman [2].

Pola perkotaan berkaitan dengan karakteristik spasial dan struktur fisik suatu daerah pada waktu tertentu. Pada dewasa ini, dalam meneliti karakteristik spasial suatu kawasan telah dikenal dengan menggunakan analisis spatial metric. Spatial metric dapat didefinisikan sebagai indeks-indeks kuantitafif yang dapat menjelaskan struktur dan pola suatu lahan berdasarkan informasi perhitungan-perhitungan teori dan geometri [3].
Salah satu penelitan dengan analisis tersebut pernah diterapkan guna mengidentifikasi karakteristik spasial dari kawasan permukiman terencana dan tidak terencana di Dar es Salaam dan New Delhi [1]. Penelitian lainnya juga pernah dilakukan di Pekalongan guna menganalisis dinamika pola spasial penggunaan lahan, yang difokuskan pada pola terkumpul dan diversitas yang terjadi di daerah pesisir.

Sebagai ibu kota dan pusat pemerintahan dan perekonomian provinsi Papua, Kota Jayapura memiliki pertumbuhan penduduk mencapai $2.83 \%$ dimana angka tersebut lebih tinggi dibandingkan dengan rata-rata tingkat pertumbuhan penduduk di Indonesia yakni sebesar $1.31 \%$. Kota Jayapura telah mengalami perkembangan yang sangat pesat yang ditandai dengan sarana dan prasarana pembangunan yang kian meningkat. Seperti di kota-kota besar lainnya, kawasan permukiman di pusat Kota Jayapura bertumbuh dan semakin padat mengakibatkan harga lahan semakin mahal. Dimana telah terjadi alih fungsi lahan dari kawasan lindung dan kawasan pertanian menjadi kawasan permukiman yang cukup tinggi yakni dengan peningkatan kawasan permukiman dari $2903 \mathrm{Ha}$ pada tahun 2007 menjadi 8537 Ha pada tahun 2013. Pertumbuhan permukiman di Kota Jayapura memiliki pola spasial yang beragam mengikuti kondisi topografi dengan kecenderungan semi kompak dan menyebar mengikuti kondisi lahan setempat [4]. Adapun pada tahun 2014, kebutuhan masyarakat terhadap perumahan meningkat rata-rata $5 \%$ per tahun. Dimana ratio penduduk dengan rumah yang tersedia di Kota Jayapura adalah 1: 7,13, sedangkan yang ideal adalah 1:5 Jiwa. Sayangnya kondisi perekonomian sebagian warga yang rendah mengakibatkan mereka untuk bertempat tinggal di daerah yang kurang memadai karena pembangunan rumah dilakukan di perbukitan, lereng terjal dan di atas permukaan air, seperti yang terdapat di Kawasan APO, Kloofkamp, Polimak, dan permukiman pantai [5].

Selama ini penelitian terkait karakteristik spasial kawasan permukiman di Kota Jayapura masih kurang terutama dengan menggunakan spatial metric. Sebagai kota yang mengalami proses urbanisasi yang cukup pesat, maka dilakukanlah penelitian ini guna mengetahui karakteristik kawasan permukiman yang berkembang di Kota Jayapura khususnya di Distrik Jayapura Selatan yang merupakan distrik dengan kepadatan tertinggi di Kota Jayapura. 


\section{II.METODE PENELITIAN}

\section{A. Area Studi}

Penelitian mengambil dua kawasan permukiman dengan pola spasial yang berbeda di Distrik Jayapura Selatan yakni Kawasan Permukiman Polimak dan Jaya Asri dengan luas yang sama yakni masing-masing 21.2 ha. Jaya Asri terletak di Kelurahan Entrop dan merupakan permukiman terencana yang dimiliki oleh developer. Sedangkan Polimak terletak di Kelurahan Ardipura dan merupakan permukiman informal.

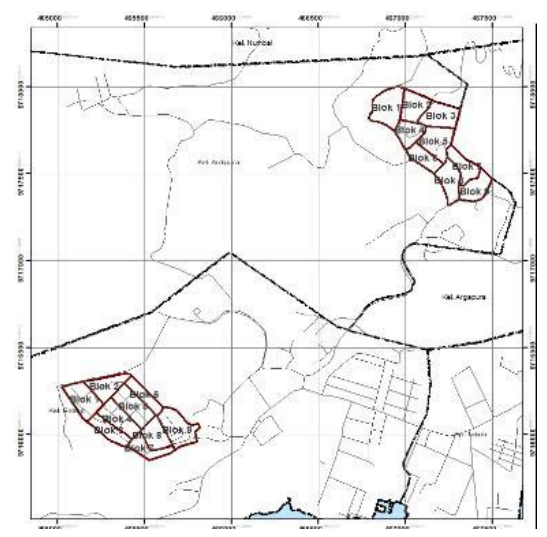

Gambar 1. Peta area studi.

\section{B. Analisis Pola Bangunan Kawasan Permukiman}

Untuk menganalisis pola bangunan kawasan permukiman dapat dilakukan dengan metode Spatial Metric. Metode Spatial metric sendiri digunakan untuk menguantitatifkan bentuk spasial pola bangunan pada kawasan permukiman dengan menggunakan bantuan software Fragstats. Adapun input untuk metode spatial metric ini adalah peta bangunan di kawasan permukiman Jaya Asri dan Polimak yang didigitasi menggunakan citra satelit Quickbird Google Earth tahun 2017.

Karena spatial metrik memiliki sifat kesatuan dalam mendeskripsikan heterogentitas landscape secara ringkas, merata-ratakan nilai metrik pada suatu kawasan dapat mengarah pada interpretasi yang tidak tepat, dimana perubahan yang tercermin dalam suatu metrik tidak dapat dikaitkan dengan lokasi tertentu. Sehingga sebaiknya area suatu studi penelitian dipecah-pecah menjadi unit yang lebih kecil [5]. Jika ditotalkan terdapat 18 blok dalam penlitian ini, dimana penentuan jumlah blok tersebut mengikuti penentuan sample yakni minimum perbandingan jumlah sample terhadap variable bebas adalah $5: 1$.

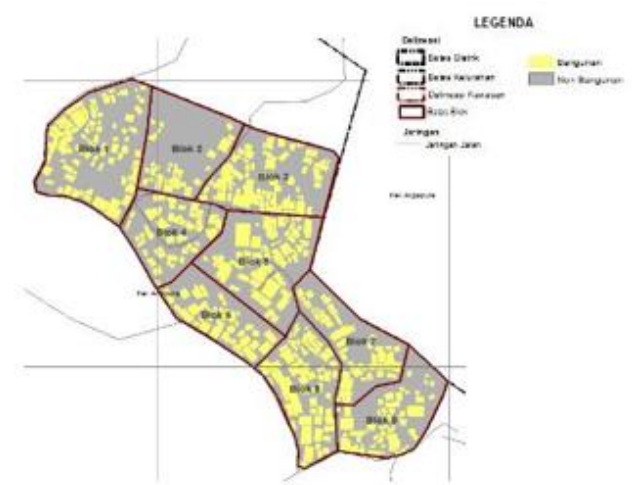

Gambar 2. Peta Pembagian blok pada area studi 1 (Polimak).

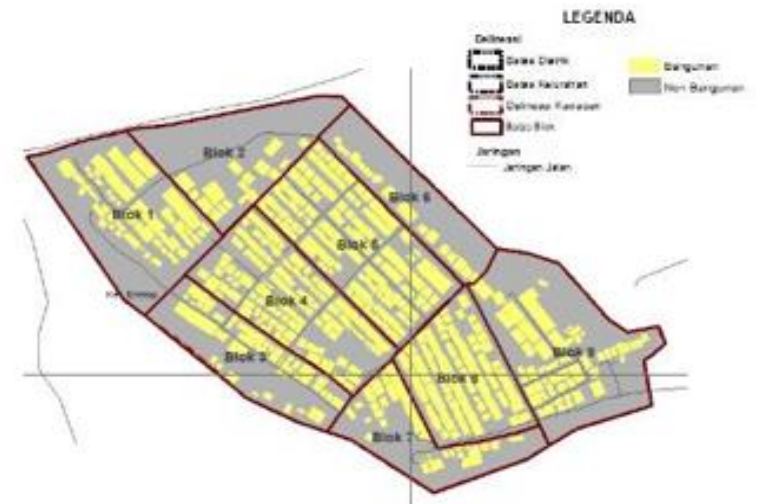

Gambar 3. Peta Pembagian blok pada area studi 2 (Jaya Asri).

Dalam melakukan analisis spatial metric, penelitian ini menggunakan level landscape guna mengetahui pola bangunan kawasan permukiman secara keseluruhan. Adapun metrik yang akan dihitung dalam penelitian ini adalah sebagai berikut 1. PD (Patch Densiy)

PD adalah kepadatan patch di level class atau landscape dengan menghitung jumlah patch per hektar. PD mempresentasikan jumlah patch bangunan permukiman yang ada dengan susunan dan konfigurasinya di landscape. Semakin tinggi nilai PD mengindikasikan semakin berfragmen dan tersebar struktur spasial kawasan permukiman dan semakin rendah nilai PD maka kawasan permukiman tersebut semakin berkumpul. Dengan menggunakan software Fragstats, metric ini dapat dikalkulasikan dengan rumus:

$$
P D=\frac{N}{A}(10,000)(100)
$$

Dimana:

Unit: No./100 ha

$\mathrm{N}$ : jumlah patch di landscape

A: luas landscape (m2)

Gambar 4 mengilustrasikan konsep PD, dimana walaupun memiliki luas yang sama PD class biru yang terkumpul memiliki nilai PD 1/ha (gambar pertama) yakni nilai PD yang lebih rendah dibandingkan ketika patch dengan class biru itu menyebar.
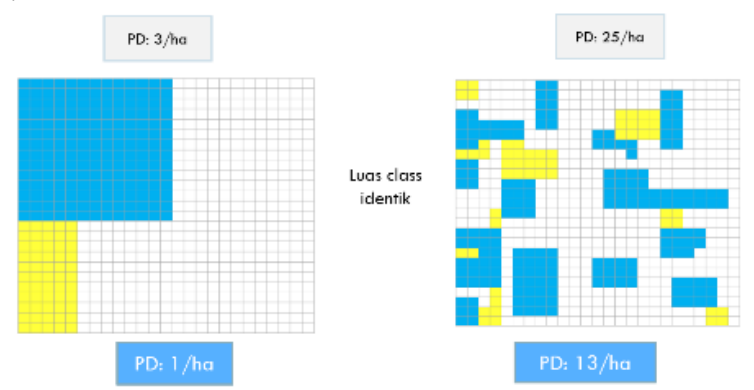

Gambar 4. Illustrasi metrik PD.

\section{LPI (Largest Patch Index)}

LPI merupakan persentase urban patch dengan ukuran terbesar yang dibagi dengan total area urban. Oleh karena itu, LPI dapat menggambarkan dominansi suatu pusat urban pada suatu wilayah. Dimana ketika nilai LPI mendekati angka 0 maka wilayah tersebut memiliki Kawasan terbangun yang berbentuk polisentrik dan berfragmen sedangkan ketika LPI mendekati 100 maka pada seluruh lansekap tersebut terdiri dari satu urban patch. 


$$
\mathrm{LPI}=\frac{\underset{\mathrm{max}\left(\mathrm{a}_{\mathrm{ij}}\right)}{\mathrm{A}}}{\mathrm{m}} * 100
$$

Dimana:

Unit: persentase (\%)

$\max$ (aij): luas patch terbesar (m2)

A: luas lansekap (m2)

Gambar 5 menunjukkan bahwa semakin kecil patch terbesar atau pusat urban maka nilai LPI akan semakin kecil seperti yang dapat dilihat pada lansekap gambar pertama, dan jika patch tersebut seluas lansekap maka LPI akan meningkat mencapai $100 \%$ seperti pada gambar ketiga.

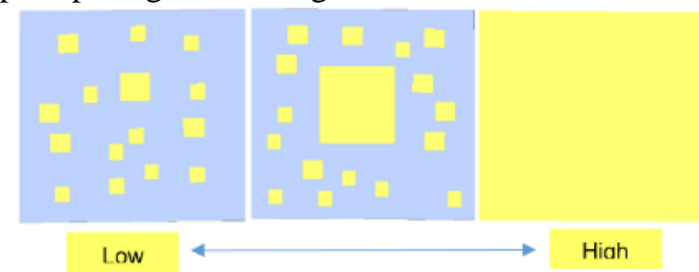

Gambar 5. Illustrasi Metrik LPI.

\section{LSI (Landscape Shape Index)}

LSI merupakan salah satu metric yang dapat mengkarakteristikan urban sprawl dengan mengukur rasio garis keliling terhadap area dimana total garis tepi dibandingkan terhadap lansekap dengan bentuk persegi berukuran sama tanpa garis tepi di dalamnya. Ketika nilai LSI mendekati angka 1 maka Kawasan urban akan cenderung berbentuk persegi atau lingkaran (kompak) sedangkan nilai LSI akan meningkat tanpa batas jika bentuk patch semakin kompleks atau garis tepi semakin panjang.

$$
L S I_{i}=0.25 \sum_{j=1}^{n} e_{i j} / \sqrt{A}
$$

Dimana:

Unit: tanpa unit

Eij: total Panjang garis tepi patch

A: luas lansekap $(\mathrm{m} 2)$

Dari Gambar 6 dapat dilihat walaupun terdiri luas patch yang sama namun jika susunan patch berbeda maka bentuk patch yang terbentuk akan berbeda. Karena metrik LSI dihitung berdasarkan garis keliling maka semakin terkumpul patchnya dan membentuk kesatuan patch yang regular maka nilai LSI akan semakin rendah seperti pada di gambar pertama. Namun jika patch tersebar membentuk beberapa kesatuan patch dengan bentuk yang kompleks maka nilai LSI akan semakin tinggi.

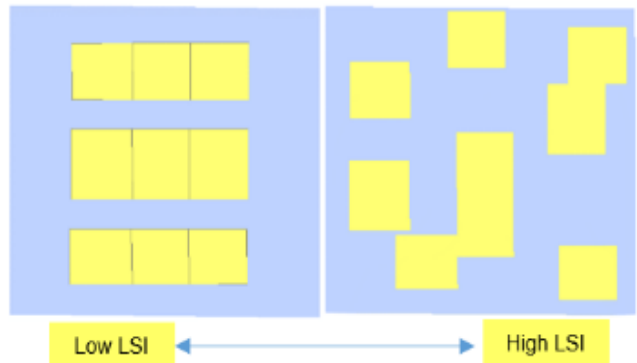

Gambar 6. 1lustrasi Metrik LSI.

4. MPS (Mean Paatch Size) / AREA_MN (Mean Area)

MPS adalah rata-rata ukuran patch yang membentuk landscape. MPS dapat digunakan untuk menganalisis luas patch bangunan permukiman. Dengan menggunakan software Fragstats, metric ini dapat dikalkulasikan dengan rumus:

$$
\text { MPS }=\frac{A}{N}\left(\frac{1}{10,000}\right)
$$

Dimana:

Unit: Ha

A: total luas landscape (m2)

$\mathrm{N}$ : jumlah patch

Gambar 7 menunjukkan bahwa semakin luas patch secara keseluruhan pada suatua lansekap maka nilai AREA_MN semakin tinggi. Hal tersebut dapat dilihat dari patch di lansekap gambar pertama memiliki ukuran yang lebih besar sehingga menghasilkan nilai MPS yang lebih tinggi dibandingkan dengan lansekap di Gambar 6.

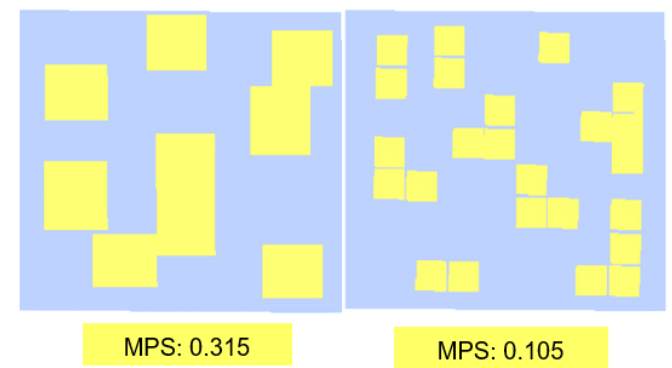

Gambar 7. Illustrasi Metrik MPS.

\section{HASIL DAN DISKUSI}

\section{A. Pola Bangunan Kawasan Permukiman Polimak}

Kawasan Permukiman Polimak cenderung memiliki bangunan rumah dengan pola tersebar dan jaringan jalan yan mengikuti kondisi topografi setempat dan ketersediaan RTH yang tercampur di antar bangunan perumahan sehingga membentuk pola polisentris, dimana bangunan-bangunan tersebut pada umumnya terkumpulnya menyatu pada beberapa titik-titik area karena memiliki ketinggian yang sama. Oleh sebab itu, nilai metrik spasial kawasan permukiman Jaya Asri dapat dilihat pada Tabel 1 .

Tabel 1.

Nilai Spatial Metric di Kawasan Permukiman Polimak

\begin{tabular}{cllcc}
\hline \hline BLOK & \multicolumn{1}{c}{ PD } & LPI & LSI & AREA_MN \\
\hline 1 & 1817.3151 & 5.7499 & 1.2561 & 0.0175 \\
2 & 970.5740 & 1.9544 & 1.2649 & 0.0144 \\
3 & 1298.1559 & 6.4755 & 1.2654 & 0.0283 \\
4 & 1363.0406 & 3.6278 & 1.2960 & 0.0225 \\
5 & 1169.2177 & 5.1800 & 1.3571 & 0.0323 \\
6 & 1377.2524 & 4.7630 & 1.5358 & 0.0265 \\
7 & 1198.5019 & 7.0412 & 1.5739 & 0.0267 \\
8 & 1582.9742 & 10.7686 & 1.4305 & 0.0295 \\
9 & 1859.9771 & 3.5292 & 1.3448 & 0.0159 \\
Keseluruhan & 1396.8994 & 1.2979 & 1.5804 & 0.0236 \\
\hline \hline
\end{tabular}

Dari hasil metrik spasial dapat diketahui bahwa:

a. PD merupakan metrik yang menghitung tingkat fragmentasi patch melalui perhitungan jumlah patch per hektar, jika dihitung secara keseluruhan Kawasan Permukiman Polimak maka nilai PD adalah 1396.8994 patch/Ha. Hal tersebut menunjukkan bahwa jika Kawasan Permukiman Polimak memiliki luas sebesar 100 ha maka terdapat 1396.8994 patch bangunan.

Dengan rentang 970.5740-1859.9771, nilai PD tertinggi terdapat di blok 9 dan terendah di blok 2 . Seperti yang dapat 
dilihat pada peta diatas, blok 9 memiliki banyak bangunan yang tidak terkumpul atau berdekatan sehingga membentuk patch bangunan yang semakin banyak sedangkan pada blok 2 , dengan jumlah bangunan yang sedikit dibandingkan blokblok lainnya, membentuk lansekap dengan jumlah patch bangunan yang sangat sedikit. Karena PD merupakan salah satu metrik yang dapat menghitung tingkat fragmentasi suatu Kawasan berdasarkan kepadatan patch bangunan, dengan kata lain blok 9 memiliki tingkat fragmentasi yang lebih tinggi dibandingkan blok 2

b. LPI yang merupakan metrik untuk menggambarkan persentase patch terbesar pada lansekap, jika dihitung secara keseluruhan Kawasan Permukiman Polimak maka nilai LPI mencapai $5.4544 \%$. Hal tersebut menunjukan bahwa persentase patch bangunan dengan luas terbesar terhadap Kawasan Permukiman Polimak mencapai 5.45\%.

Dengan rentang $1.9544-10.7686 \%$, nilai LPI tertinggi terdapat di blok 8 dan terendah di blok 2. Seperti yang dapat dilihat pada peta diatas, blok 8 memiliki barisan rumahrumah yang menyatu atau kompak sehingga membentuk patch bangunan yang lebih besar dibandingkan blok lainnya sedangkan blok 2 memiliki bangunan rumah dengan luas yang kecil dan tersebar antar setiap rumahnya sehingga membentuk patch bangunan yang kecil. Karena LPI merupakan salah satu metrik yang dapat menghitung tingkat kompak suatu Kawasan, dengan kata lain blok 8 memiliki tingkat kompak yang lebih tinggi sedangkan blok 2 memiliki tingkat kompak yang lebih rendah.

c. LSI merupakan metrik yang menghitung rasio garis keliling patch terhadap lansekap, jika dihitung secara keseluruhan Kawasan Permukiman Polimak maka nilai LSI adalah mencapai 1.3694. ketika nilai LSI mendekati angka 1 maka Kawasan tersebut akan cenderung berbentuk regular(persegi /lingkaran) dan kompak, sehingga Kawasan permukiman Polimak cenderung sedikit kompak dan sedikit berbentuk regular.

Dengan rentang 1.2561-1.5739, nilai LSI tertinggi adalah pada blok 7 dan terendah pada blok 1. Seperti yang dapat dilihat pada peta diatas, blok 7 memiliki susunan bangunan yang menyebar dan memanjang, sedangkan blok 1 cenderung terkumpul dalam lingkaran. Dengan kata lain, blok 1 cenderung lebih kompak dan berbentuk lebih regular sedangkan blok 7 cenderung lebih berfragmen dan berbentuk kompleks

d. AREA_MN merupakan metrik yang mengukur rata-rata ukuran patch yang membentuk lansekap, dimana nilai AREA_MN pada Kawasan permukiman Polimak adalah 0.0237 Ha. Hal tersebut menunjukkan bahwa rata-rata ukuran patch bangunan atau rumah di Kawasan Permukiman Polimak adalah seluas 0.0237 .

Dengan rentang 0.0144-0.0323 Ha, rata-rata luas patch bangunan terbesar terdapat di blok 5 dan terendah di blok 2 . Seperti yang dapat dilihat pada peta diatas bahwa blok 5 pada umumnya terdiri dari bagunan-bangunan yang lebih besar sedangkan blok 2 terdiri dari bangunan-bangunan dengan luas yang lebih kecil.

\section{B. Pola Bangunan Kawasan Permukiman Jaya Asri}

Kawasan Permukiman Jaya Asri cenderung memiliki bangunan-bangunan yang berbaris dan berdempetan dengan pola grid yang setiap blok bangunan terpisahkan dengan jalan sehingga bangunan cenderung tersebar secara merata di setiap area serta memiliki RTH yang terletak di luar komplek mengelilingi komplek permukiman. Oleh sebab itu, nilai metrik spasial kawasan permukiman Jaya Asri dapat dilihat pada Tabel 2.

Tabel 2.

Nilai Spatial Metric di Kawasan Permukiman Jaya Asri

\begin{tabular}{cccr}
\hline \hline BLOK & LPI & LSI & AREA_MN \\
\hline 1 & 5.05507 & 1.4053 & 0.037 \\
2 & 2.1671 & 1.505 & 0.0232 \\
3 & 5.8202 & 1.6449 & 0.0233 \\
4 & 4.6313 & 1.5583 & 0.0246 \\
5 & 4.6741 & 1.5275 & 0.0385 \\
6 & 2.8633 & 1.7928 & 0.0227 \\
7 & 9.5261 & 1.834 & 0.0226 \\
8 & 13.9668 & 1.3483 & 0.0564 \\
9 & 4.2599 & 1.4155 & 0.0258 \\
Keseluruhan & 1.3788 & 1.4245 & 0.0305 \\
\hline \hline
\end{tabular}

a. PD merupakan metrik yang menghitung tingkat fragmentasi patch melalui perhitungan jumlah patch per hektar, jika dihitung secara keseluruhan Kawasan Permukiman Jaya Asri maka nilai PD adalah 1104.2059 patch/Ha. Hal tersebut menunjukkan bahwa jika Kawasan Permukiman Jaya Asri memiliki luas sebesar 100 ha maka terdapat 1104.2059 patch bangunan.

Dengan rentang 620.4299-1851.0124 patch/ha, nilai PD tertinggi terdapat di blok 4 dan terendah di blok 2. Seperti yang dapat dilihat pada peta diatas, blok 4 memiliki banyak bangunan yang tidak terkumpul atau berjauhan sehingga membentuk patch bangunan yang semakin banyak sedangkan pada blok 2, dengan jumlah bangunan yang sedikit dibandingkan blok-blok lainnya, membentuk lansekap dengan jumlah patch bangunan yang sangat sedikit. Karena PD merupakan salah satu metrik yang dapat menghitung tingkat fragmentasi suatu Kawasan berdasarkan kepadatan patch bangunan, dengan kata lain blok 4 memiliki tingkat fragmentasi yang lebih tinggi dibandingkan blok 2 .

b. LPI yang merupakan metrik untuk menggambarkan persentase patch terbesar pada lansekap, jika dihitung secara keseluruhan Kawasan Permukiman Jaya Asri maka nilai LPI mencapai $1.3788 \%$. Hal tersebut menunjukan bahwa persentase patch bangunan dengan luas terbesar terhadap Kawasan Permukiman Jaya Asri mencapai 1.3788\%.

Dengan rentang 2.1671-13.9668\%, nilai LPI tertinggi terdapat di blok 8 dan terendah di blok 2. Seperti yang dapat dilihat pada peta diatas, blok 8 memiliki barisan rumahrumah yang menyatu tanpa ada jarak yang besar sehingga membentuk patch bangunan yang lebih besar dibandingkan blok lainnya sedangkan pada blok 2 setiap rumahnya tersebar sehingga membentuk patch bangunan yang kecil. Karena LPI merupakan salah satu metrik yang dapat menghitung tingkat kompak suatu Kawasan, dengan kata lain blok 8 memiliki tingkat kompak yang lebih tinggi sedangkan blok 2 memiliki tingkat kompak yang lebih rendah atau lebih berfragmen.

c. LSI merupakan metrik yang menghitung rasio garis keliling patch terhadap lansekap, jika dihitung secara keseluruhan Kawasan Permukiman Jaya Asri maka nilai LSI adalah mencapai 1.4245. ketika nilai LSI mendekati angka 1 maka Kawasan tersebut akan cenderung berbentuk 
regular(lingkaran) dan kompak, sehingga Kawasan permukiman Jaya Asri cenderung sedikit kompak dan sedikit berbentuk regular.

d. Dengan rentang 1.3483-1.834, nilai LSI tertinggi adalah pada blok 7 dan terendah pada blok 8 . Seperti yang dapat dilihat pada peta diatas, blok 7 memiliki susunan bangunan yang menyebar dan memanjang, sedangkan blok 8 cenderung memiliki bangunan dengan jarak yang berdekatan Dengan kata lain, blok 8 cenderung lebih kompak dan berbentuk lebih regular sedangkan blok 7 cenderung lebih berfragmen dan berbentuk kompleks

e. AREA_MN merupakan metrik yang mengukur rata-rata ukuran patch yang membentuk lansekap, dimana nilai AREA_MN pada Kawasan permukiman Jaya Asri adalah $0.03045 \mathrm{Ha}$. Hal tersebut menunjukkan bahwa rata-rata ukuran patch bangunan atau rumah di Kawasan Permukiman Jaya Asri adalah seluas 0.03045 Ha. Dengan rentang 0.0144$0.0323 \mathrm{Ha}$, rata-rata luas patch bangunan terbesar terdapat di blok 8 dan terendah di blok 7. Seperti yang dapat dilihat pada peta diatas bahwa blok 8 pada umumnya terdiri dari bagunan-bangunan yang lebih besar sedangkan blok 5 terdiri dari bangunan-bangunan dengan luas yang lebih kecil.

C. Perbandingan Pola Bangunan Kawasan Permukiman Jaya Asri dan Polimak

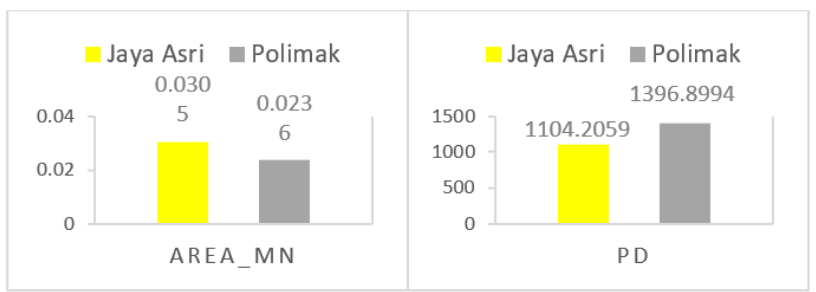

(a)

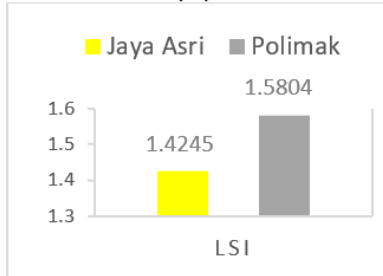

(c) (b)

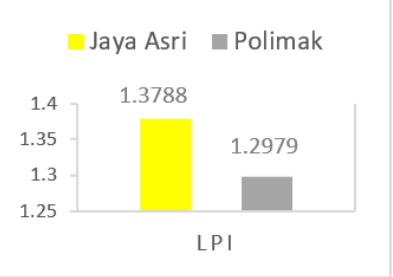

(d)
Gambar 8. Grafik Perbandingan Nilai Metrik antara Jaya Asri dan Polimak.

Sebagai Kawasan permukiman yang direncanakan, Kawasan Permukiman Jaya Asri memiliki karakteristik spasial yang berbeda dengan Kawasan Permukiman Polimak. Dimana berdasarkan hasil metrik spasial diatas, perbedaan karakteristik spasial kedua Kawasan tersebut adalah sebagai berikut:

a. Dari setiap keseluruhan Kawasan permukiman nilai metrik PD terbesar adalah pada Kawasan permukiman PD dengan selisih 292.6935 patch/ha dibandingkan Polimak. Hal tersebut menunjukkan bajwa berdasarkan distribusi dan kepadatan patch bangunan, Polimak memiliki bangunan yang tersebar atau lebih berfragmen dibandingkan Jaya Asri.

b. Dari setiap keseluruhan Kawasan, nilai metrik LPI terbesar adalah pada Kawasan permukiman Jaya Asri dengan selisih $0.089 \%$ lebih besar dibandingkan Polimak. Hal tersebut menunjukkan bahwa berdasarkan persentase patch bangunan terbesar yang terdapat pada setiap Kawasan permukiman, Jaya Asri cenderung memiliki tingkat kompak yang lebih tinggi dibandingkan dengan Polimak

c. Dari setiap keseluruhan Kawasan permukiman, nilai metrik LSI terbesar adalah pada Kawasan Permukiman Polimak dengan selisih 0.16 lebih besar dibandingkan Jaya Asri. Hal tersebut menunjukkan bahwa berdasarkan rasio garis keliling patch bangunan terhadap lansekap Kawasan permukiman, Jaya Asri cenderung lebih kompak dan berbentuk lebih regular dibandingkan Polimak.

d. Dari setiap keseluruhan Kawasan permukiman, nilai metrik AREA_MN terbesar adalah pada Kawasan Permukiman Jaya Asri dengan selisih 0.0069 Ha lebih besar dibandingkan Polimak. Hal tersebut menunjukkan patch bangunan di Jaya Asri pada umumnya lebih besar besar dibandingkan dengan Polimak.

\section{KESIMPULAN}

Berdasarkan hasil analisis spatial metric yang dilakukan, dapat disimpulkan bahwa kedua Kawasan yang menjadi objek penelitian memiliki karakteristik spasial yang berbeda. Kawasan Permukiman Jaya Asri memiliki nilai metrik PD, LPI, AREA_MN yang lebih besar dan nilai metrik LSI yang lebih sedikit dibandingkan Polimak. Dengan kata lain Jaya Asri yang merupakan salah satu permukiman terencana di Kota Jayapura memiliki karakteristik spasial yakni pola bangunan yang lebih kompak, memiliki rata-rata bangunan yang lebih luas dan berbentuk lebih regular jika dibandingkan dengan Polimak yang merupakan salah satu permukiman tidak terencana di Kota Jayapura.

\section{DAFTAR PUSTAKA}

M. Kuffer and J. Barros, "The Use of Spatial Metrics in VHR Remotely Sensed Images," in Procedia Environmental Sciences Urban Morphology of Unplanned Settlements, 2011.

T. Ramachandra, A. Bharath, and M. Sowmyashree, "Monitoring urbanization and its implications in a mega city from space: Spatiotemporal patterns and its indicators," J. Environ. Manage., 2014.

M. Herold, "Remote Sensing and Spatial Metrics - A New Approach for the Description of Structures and Changes in Urban Areas," 2001. C. Lawene, "Pengembangan Kawasan Permukiman Di Kota Jayapura," Universitas Sam Ratulangi Manado, 2017.

M. Chakraborty, "An approach towards urban form analysis and landuse classification: A case of Ahmedabad, India," International Institute for Geo-Information Science and Earth Observation, 2009. 